\title{
RECONSTRUCTING THE ORIGINS OF REALISTIC JURISPRUDENCE: A PREQUEL TO THE LLEWELLYN-POUND EXCHANGE OVER LEGAL REALISM
}

\begin{abstract}
N.E.H. HULL*
I am no historian and this paper does not purport to be history. Rather, it is an appeal for history. It is a sad commentary on our dogmatics that sales cases over a hundred and fifty years and more than fifty jurisdictions have been treated as if they floated free of time, place and person. Whereas it is time, place, person and circumstance which give them meaning. A few major trends are here presented. But not as history. History calls for detailed knowledge, for detailed background, and for discrimination even more detailed.-Karl Llewellyn ${ }^{1}$
\end{abstract}

\section{INTRODUCTION}

You may have heard this story before; everyone who goes to law school is exposed to some variant of it. During the first half of the twentieth century, American Jurisprudence ${ }^{2}$ found its own voice. Breaking

Copyright (ㄷ) 1990 N.E.H. Hull.

* Associate Professor, The State University of New Jersey-Rutgers, School of Law-Camden. Ohio State University, B.A., 1974; Columbia University, Ph.D., 1981; University of Georgia, J.D., 1985.

This article is dedicated to Professor Leslie A. Hull.

Research for this article was funded by the American Couneil of Learned Societies, Rutgers School of Law-Camden, the Rescarch Council of Rutgers University, the Charles Warren Center for Studies in American History and the American Bar Foundation.

Earlier versions of this article were presented as a Minerva Lecture at Union College, Schenectady, N. Y. and at the New York University Law School Legal History Seminar, the Rutgers Law School Faculty Forum, and the Fellows Seminar of the Rutgers University Center for the Critical Analysis of Contemporary Culture. I benefited enormously from the comments of colleagues at each of those presentations.

I am grateful to the Harvard Law School Library, the University of Chicago Law Library, and the Northwestern University Library for permission to quote from the Pound, Llewellyn, and John Henry Wigmore Papers, respectively. I want to thank Judith W. Mellins, David Delorenzo, and Pamela Ross, archivist-librarians at the Harvard Law School Library, Charles Ten Brink of the University of Chicago Law School Library, and Kevin Leonard of the Northwestern University Library for their generous assistance.

Finally, I would like to thank my research assistant, Williamjames B.P.H. Hoffer, for his inadequately compensated assistance in multiple archives and libraries.

1. Llewellyn, On Warranty of Quality, and Society, 36 CoL. L. Rev. 699, 699 n.* (1936).

2. Legal thought, philosophy, or Jurisprudence was once defined as "any thoughtful generalizing about anything that has a legal reference for the purpose of which reaches beyond solving the case of next Tuesday." TRANSCRIPT OF K. LLEWELLYN'S JURISPRUDENCE LECTURES AT UNIVER- 
from their predecessors' subservience to British and continental jurisprudents, a cadre of American law professors, bravely marching under the battle flag of "Legal Realism," lured the dragon of legal formalism from its cave. In heroic combat that echoed through the pages of the Columbia Law Review and the Harvard Law Review, ${ }^{3}$ St.-George-the-Legal Realist slew the dragon of formalism by proving that judges did not follow the rules they said they were following. The Legal Realists revealed Legal Formalism to be a sham, a "style of reasoning"4 masking personal and policy preferences. On the field of their triumph, the Legal Realists deployed a new theory of how courts and judges worked. Realist theoreticians, riding off boldly im many directions, called for a commitment to the social scientific study of how courts worked, a behavioral or psychological explanation of the way the legal system functioned, a skepticism about the received wisdom of legal principles and rules-particularly those that claimed to cover every case-and a passionate belief in replacing an impersonal, formahistic legal structure with one conforming to a functional reality. ${ }^{5}$ The end of the story is both comforting and fitting: we are all reahists now. ${ }^{6}$

STTY of Chicago School of LAw, KarL Llewellyn Papers [hereinafter Llewellyn Papers] C.F.3. This is what I call Jurisprudence with an uppercase $J$. There is also a jurisprudence with a lower case $j$, the legal philosophy implicit in judges' opinions, lawyers' briefs, and legislators' statutes. Jurisprudence, with a large $J$ is conscious and serious thought about the law and touches on political theory, social and political history, and most other areas of humanist or social science study. Of course, the philosophizing and dissection carried on by law professors, political scientists, and philosophers can and has had an impact on jurisprudence with the lower case $j$ and consequently on our social and political system generally.

3. The famous Rcalist debate between Karl Llewellyn and Roscoe Pound was carried on in three articles in those two journals. See Llewellyn, A Realistic Jurisprudence-The Next Step, 30 CoLum. L. Rev. 431 (1930) [hereinafter Llewellyn, Next Step]; Pound, The Call for a Realist Jurisprudence, 44 HARv. L. REv. 697 (1931); Llewellyn, Some Realism about Realism, A Reply to Dean Pound, 44 HaRv. L. Rev. 1222 (1931) [Hereinafter Llewellyn, Reply]. For a detailed look at the debate, see Hull, Some Realism about the Llcwellyn-Pound Exchange over Realism: The Newly Uncovered Private Correspondence, 1927-1931, 1987 WIS. L. REV. 921.

4. K. Llewellyn, The Common law Tradition: Deciding appeals (1960).

5. The secondary literature analyzing these aspects of Legal Realism is extensive. See, e.g., L. Kalman, Legal Realism at Yale, 1927-60 (1986); W. Rumble, American Legal Realism: SKepticism, REFoRM, AND THE JUdicial Process (1968); Bloustein, Logic and Legal Realism: The Realist as a Frustrated Idealist, 50 CORNELL L.Q. 24 (1964); Schlegel, American Legal Realism and Empirical Social Science: From the Yale Experience, 28 BuFr. L. Rev. 459 (1979); Schlegel, American Legal Realism and Empirical Social Science: The Singular Case of Underhill Moore, 29 BuFF. L. REv. 195 (1980).

6. The conventional story is most often promulgated by law teachers and legal text writers, not legal historians. Grant Gilmore credits the school of Legal Realism with making "a clean sweep of the errors of the past." Gilmore, Legal Realism: Its Cause and Cure, 70 YALE L. J. 1037, 1037 (1961). He posits the beginning of the revolution with Holmes and then jumps to the Realists as the critics of nineteenth-century Jurisprudence. He never mentions Roscoe Pound. Id. at 1039. Another influential article recounting the conventional story appears in a popular anthology often assigned to law students. Mensch, The History of Mainstream Legal Thought, in THE PoLITICS OF 
If we were all "post-structuralists,"7 content with an account of the origins of legal realism that transcended the original actors to live on its own, there would be no reason to revise the conventional account. Much "legal history," particularly the legal history taught in law school classes, operates at this level. And that makes sense because law professors employ legal history in the classroom to introduce and define the contours of legal doctrine. Insofar as legal doctrine is taught in an abstract and acontextual way, so "legal history" is extracted from historical fact. In this acontextualization of "legal history," the law professors have company. Today many intellectual historians, borrowing from post-structural schools of literary criticism, have adopted an acontextual canon. "[L]iterature has returned to history," writes David Harlan, "unfurling her circus silks of metaphor and allegory, misprision and aporia, trace and sign, demanding that historians accept her mocking presence right at the heart of what they had once insisted was their own autonomous and truly scientific discipline." 8 This approach to the history of ideas divorces them from the actual discourse, the exchange of words and symbols among living thinkers. It runs the risk of turning historical protagonists into cyphers, names attached to categories. ${ }^{9}$ That is a risk

LAW 18-39 (D. Kairys ed. 1982). Mensch periodizes twentieth-century Jurisprudence thus: Classical Legal Consciousness (1885-1935), followed by The Realist Challenge (1920-1939), followed by Attempts at Modern Reconstruction (1940-Present). Id. at 23, 26, 29. Again, Pound and his Progressive-Pragmatic colleagues are largely ignored. Variations of this story also appear in standard texts, such as C. KNapp \& N. CRYstal, Problems in Contract LaW: CASes and Materials 10-11 (2d ed. 1987) (Pound and sociological jurisprudence dismissed in a single sentence followed by long description of Legal Realists that could have been applied equally to Pound and his ProgressivePragmatic contemporaries); G. Christie, JuRisprudence: TeXt and Readings on the PHILOSOPHY OF Law 645-752 (1973). Professor Christie devotes an entire chapter, Part Two: Modern Legal Philosophy to Legal Realism. According to Professor Christie, the first Realist Jurisprudent is Holmes, followed by Herman Oliphant, Joseph C. Hutcheson, Jerome Frank, and Karl Llewellyn. There is a note on the Debate between Llewellyn and Pound, but not a single selection from Pound's work is included.

7. Art Berman defines the post-structualist approach thus: "In post-structuralism, knowledge of the world derives from the interaction between a primary, originally contentless, subjectivity and a language that pre-exists the user of it . . . all truth is eventually undermined." FROM THE NEW Criticism to Deconstruction, The Reception of Structuralism and Post-StructuralISM 173-74 (1988). In other words, post-structuralism is anti-realistic and subjective in a sense that would deny traditional contextualist history. See also papers and comments presented at the conference, "Realism and Representation," November 10-12, 1989, on file at the Rutgers University Center for the Critical Analysis of Contemporary Culture.

8. Harlan, Intellectual History and the Return of Literature, 94 AM. HIST. Rev. 581, 581 (1989).

9. Harlan acknowledges that the deconstructionist or post-structuralist linguistic approach to intelleetual history has attracted a siguificant backlash of contextualist critics, including J.G.A. Pocock, Quentin Skinner, and David Hollinger. Id. at 583. Hollinger, indeed, published a reply to Harlan in the same issue of the American Historical Review in which he refutes Harlan's claim that the post-structuralists now dominate the field of intellectual history. See Hollinger, The Return of the Prodigal: The Persistence of Historical Knowing, 94 AM. HIST. REv. 610, 620-21 (1989) ("Trends 
we should avoid; there already are enough abstract categories and dehumanized doctrines in legal scholarship.

Seen from a contextuahst perspective, the conventional story of Legal Realism's birth is wrong. ${ }^{10}$ That is to say, once we abandon the post-structuralist position, we are able to ask a series of questions that we could not ask before. These questions drive us deep into the exchange of ideas among legal scholars at a particular point in time. They are questions whose answers tell us why these scholars argued as they did and what they meant to tell each other. Research into the manuscripts of Roscoe Pound, Karl Llewellyn, and John Henry Wigmore, reveals a different and highly human account of the origins of Legal Reahsm.

In broad outline, the story should read: in the first three decades of the twentieth century, legal academics fashioned an autonomous, indigenous jurisprudential movement, but it was not, at least at first, Legal Realism. Instead, a group of law professors, jurists, and philosophers, led or at least inspired by Dean Roscoe Pound of Harvard Law School,

in literary theory do come and go with some rapidity ... "but the thing now is postpoststructuralism.'").

10. While the conventional story is popular and dominates general consciousness, there have been scholars who, to varying degrees, recognized the intermediate movement of Pound and his generation. Harold Reuschlein, Thomas Cowan, and Edgar Bodenheimer of the generation contemporary to or immediately following the Realists tried to give Pound and the other pre-Realist pragmatists their due. Reuschlein, in the section of his book dealing with Our Contemporaries, starts with the Fatherhood of Holmes, followed by The Pre-Emptive Roscoe Pound, then deals with Harlan Fiske Stone, Arthur T. Vanderbilt, and John Henry Wigmore; and Albert Kocourek and the Pragmatists (primarily John Dewey) in several smaller sections, and then deals with the Realists. $\mathrm{H}$. Reuschlein, JURISPRUdence: Irs American Prophers 95-274 (1951). Coivan, for example, treats The Realists as one subcategory in his chapter on Sociological Jurisprudence. T. CowAN, THE AMERICAN JURISPRUDENCE READER 157-89 (1956). Bodenheimer, while giving Pound's sociological jurisprudence and legal realism equal weight in the title of his Chapter VII, explicitly recognizes, "The realist movement in American jurisprudence may be characterized as a radical wing of the sociological school of law." E. BODENHEIMER, JURISPRUDENCE 111, 124 (rev. ed. 1974). This generation also included Ervin $\mathrm{H}$. Pollack, whose posthumously published text treats Sociological Jurisprudence and Pound in a chapter equal to the one devoted to American Legal Realism. E. Pollack, JuRisprudence: Principles and Applications 635-910 (1979).

Probably the strongest modern defense of Pound's centrality to modern jurisprudence and his influence on legal realism in recent years is by Wilfrid Rumble. Rumble admits, "Once it is realized that ... sociological jurisprudence had been formulated in the first dozen years of this century, the debt of the legal realists to Pound becomes clear. To a degree the realist movement was quite obviously a vigorous reassertion of doctrines the lineage of which leads back to him." W. RUMBLE, supra note 5, at 13. Nevertheless, Rumble's book is entitled and focuses on American Legal Realism, not Sociological Jurisprudence or Progressive-Pragmatism.

In a recent article, Martin P. Golding discusses Pound's central role in the pragmatic jurisprudential reforms of the early twentieth century and his contributions to legal realism, citing a comment by Llewellyn on Pound from a review of Pound's 1959 treatise. He goes on to opine that Pound "is so much unread today-undeservedly," but seems at a loss to explain why. Golding, Jurisprudence and Legal Philosophy in Twentieth-Century America-Major Themes and Developments, $36 \mathrm{~J}$. LEGAL EDUC. 441, 451 (1986). 
committed themselves to a cautious progressive reform of courts and law, pragmatic both in its own methodology and in the way it evaluated legal rules. Pound drew to himself many younger scholars, including the future inventor of the Legal Realist movement, Karl Llewellyn. Pound nurtured these scholars, supported and prodded them. They were Progressive-Pragmatists who viewed law sociologically and called for its reform.

In the 1920s, anti-radical witch-hunts outside the courtroom and conservatism within it forced law professors to choose political sides. Pound was always on the side of reform, but others felt he moved too cautiously. ${ }^{11}$ An intellectual rupture with Karl Llewellyn-in large measure prompted by an unsuccessful attempt at collaboration between the two ${ }^{12}$-led to the beginnings of the Legal Realist movement and a remarkable intellectual coup. Llewellyn split the Progressive-Pragmatists he co-opted some as Legal Realists, despite their disclaimers, and condemned the rest to the inferno of legal formalism. There were really two movements that laid the foundation for modern legal thouglit, but the reputation and legacy of one was deliberately sinothered in its bed by the other.

The contextualist enterprise applied to the origin of Legal Realism reveals that Karl Llewellyn deliberately rewrote the public version of the intellectual history of the movement to conceal Pound's vital role in it, ${ }^{13}$ even though he later conceded a significant role for Pound. ${ }^{14}$ Llewellyn's revision of the intellectual origins of legal realism in a momentary pique created significant repercussions that affected the course of all later jurisprudential scholarship. This Article offers a historical reconstruction of those intellectual origins, which should serve as a stiff antidote to acontextual Jurisprudence. It is time to rethink and reconstruct the history of the formative period of American legal thought.

\section{ROSCOE POUND}

Roscoe Pound for over thirty years held a chaired professorship and for twenty years served as dean of Harvard Law School. ${ }^{15}$ One of the

11. See infra text accompanying notes 66-73.

12. See infra text accompanying notes 116-151.

13. See infra text accompanying notes 75-76.

14. See infra text accompanying notes $152-53$.

15. For biographical information on Pound, see P. SAyre, The LIFE of Roscoe Pound (1948); D. Wigdor, Roscoe Pound, Philosopher of LAW (1974); and a series of articles by A. Lawrence MacKenzie in Boston Sunday Post, Mar. 14, 1926, at B11, col. 1, and Mar. 21, 1926, at C6, col. 1, respectively (copies in Pound scrapbook, Red Set, Harvard Law School Library) 
most prolific legal scholars of the century, ${ }^{16}$ he was also one of the most colorful figures ever to profess anything at an American university. Early in his career, while dean of the law department of the University of Nebraska, he startled the legal profession with his scathing critique of the legal system. This attack came in 1906, the heyday of political Progressivisin. ${ }^{17}$ Arguably, no one in the United States at that time was unaware of child labor, the excesses of the modern corporation, corruption in governnient (including the courts), political graft, and labor unrest. A powerful, though disorganized, national movement of reformers was hard at work to remedy society's ills.

While unrest and reform played themselves out in the arena of politics, a large proportion of the elite bar who attended the annual summer outing called the American Bar Association convention tried hard to ignore the turmoil. They cluug to the belief that they could liold the line against the ferment, or at least that noisy reform could be kept from interfering with their comfortable legal club. Into this largely smug conclave of business lawyers and conservative judges came the thirty-sevenyear-old Roscoe Pound, who stood ready to pusl the switch to electrify the gas-lit mentality of the ABA lawyers.

Pound's talk, "The Causes of Popular Dissatisfaction with the Administration of Justice,"18 laid the woes of the law at the door of overeager and legally naive legislators and, inost heretically, the judges. He criticized the bar and bench for allowing treatable symptoins to go uncorrected. Implicit in Pouud's exegesis was a "sociological" approach that he would later expound in several law review articles over the next decade. Pound einphasized, in this first talk, the cultural origins of law and its unresponsiveness to that bugaboo of the lawyers, public opinion. He was not arguing for direct democratic influence in judicial procedure-for instance, he opposed the interference of politics through the popular election of judges. ${ }^{19}$ Rather, Pound argued for judicial decisionmaking sensitive to currents of public opinion. ${ }^{20}$

Pound's theory of law flew in the face of the prevailing jurisprudence of how judges wrote their opinions and decided cases. In the late nineteenth century, legal orthodoxy clainied that judges objectively discovered principles of law as if they existed independent of concrete cases

16. See F. Setaro, A Bibliography of the Writings of Roscoe Pound (1942); G. Stratt, A Bibliography OF THE Writings of Roscoe Pound, 1940-1960 (1960).

17. R. MCCORMICK, The Party Period and Public Policy (1986); G. MOWRY, The ProGressive ErA, 1900-20: The Reform Persuasion 13, 35 (3d ed. 1972).

18. 29 A.B.A. REP. 395 (1906).

19. Id. at 400 .

20. Id. 
and floated in the ether as TRUTH. ${ }^{21}$ Fundamental principles never changed; rules of law, however, might be adapted to fit new facts, but only by a judge who reverts first to principles and then deduces congruent rules to handle unique cases. A wise judge always could find the RIGHT answer or outcoine for every case. Pound's sociological view emphasized principles over rules and argued, as a Progressive would, that rules and principles should be adapted to social, economic, and pohtical changes. Pound rejected the orthodoxy that principles could exist in an abstract dimension divorced from social interests. In this lecture to the ABA convention, Pound first articulated what many of his generation had begun to recognize, and his bold assault on the established view inspired like-minded Progressive-Pragmatists to engage in open jurisprudential rebellion.

A furor erupted at the ABA nieeting over a resolution to have Pound's talk reprinted and distributed in advance of its publication in the ABA Annual Report. ${ }^{22}$ Pound's admirers wanted his scathing critique disseminated as quickly as possible to all members of the bench and bar who had not had the opportunity to hear it for themselves. The ABA's conservative old guard responded by condemning Pound's "drastic attack" and defending the orderly, formalistic systein of justice that had prevailed for nearly half a century. The Progressives retreated in the face of the "repressed indignation of the assemblage," but the altercation signaled a new generation's open break with the old fornalist jurisprudence.

Pound had two great talents as a jurisprudent. First, he was an insightful reader and synthesizer of others's work; often he seemed to appreciate what scholars had said better than they did themselves. His second talent was his ability to identify the inportance of intellectual trends, both legal and extra-legal, and incorporate them into his view of law. His soundest works of Jurisprudence reflect these two talents. His greatest weakness as a jurisprudent was probably his tendency to obfuscate his views with pedantry. He was so enamored of comparative jurisprudence and had such a fecund talent for recall that it is often inpossible today (and, I suspect, was always impossible) to determine where Pound left his sources and spoke for himself.

21. For an excellent dissection of formalist jurisprudence, see Grey, Langdell's Orthodoxy 45 U. PiTr. L. Rev. 1 (1983).

22. The account of what happened at the meeting is taken from Wigmore, Roscoe Pound's St. Paul Address of 1906: The Spark that Kindled the White Flame of Progress, 20 J. AM. JuD. Soc'Y 176 (1937). See also Hull, Restatement and Reform: A New Perspective on the Origins of the American Law Institute, 8 LAW \& HIsT. REV. (forthcoming 1990) for an analysis of what happened in St. Paul and after among the insurgent law professors. 
The article that best displays Pound's strengths and is least marred by his weaknesses was "Mechanical Jurisprudence." 23 In it he explicitly attacked Formahism. Published in 1908, two years before Pound went to Harvard, the piece clearly articulated his Progressive-Pragmatic view of law and explicitly contrasted it with the formahism, or as he called it, the "jurisprudence of conceptions," of the late nineteenth century. He identified his sociological approach with philosophical pragmatism: "The sociological movement in jurisprudence is a movement for pragmatism as a philosophy of law ...."24 He then connected this pragmatic "jurisprudence of ends" with the ideals of Progressivism. The goals of his approach were "the adjustment of principles and doctrines to the human conditions they are to govern rather than to assume first principles; for putting the human factor in the central place and relegating logic to its true position as an instrument."25 As an example of how his Jurisprudence would revise the jurisprudence of everyday law, Pound turned to modern commercial law. Citmg Rudolph von Jhering, a Prussian Romanist who wrote mcessantly of reconciling imterests, ${ }^{26}$ Pound argued that "if a rule of commercial law were in question, the search should be for the rule that best accords with and gives effect to sound business practice."27 Pound himself criticized the American law of partnership for "deducing its rules from a conception of joint ownership and joint obligation, instead of ascertaining and giving effect to the actual situation as understood and practiced by merchants." 28

He expanded on his own approach three years after "Mechanical Jurisprudence" with a series of articles on what he then termed "Sociological Jurisprudence."29 Pound actually had inisgivings about calling his approach "Sociological Jurisprudence." In 1919, he told Thomas Reed Powell, whoin he would shortly recruit as a colleague at Harvard Law School,

Very likely the word 'sociological' is unfortunate. Certainly it is unfortunate philologically. On the other hand, I should think it a mistake to abandon it. The very fact that it is a challenge is of importance ... the radical contrast between the methods that must obtam in the present and the future and those which obtained in the nineteenth century.

23. 8 Colum. L. Rev. 605 (1908).

24. Id. at 609.

25. Id. at 609-10.

26. See R. von Jhering, The Struggle for LAW (1879) (A. Kocourek ed., J. Lalor trans. 1915).

27. Pound, supra note 23, at 610 .

28. Id. at 611 .

29. Pound, The Scope and Purpose of Sociological Jurisprudence, (pts. 1-3) 24 HARV. L. Rev. 591 (1911); 25 HARV. L. REV. 140, 490 (1912). 
The word 'sociological' seems to me important because it necessarily associates itself in men's minds with this element of change. ${ }^{30}$

At that time, sociology held a position as the most progressive and innovative of the emerging social sciences. ${ }^{31}$ What alternative to "sociological" was there? Pound had one in mind-"realism." Pound was, in that letter, invitimg Powell to give a talk to Phillips Brooks House (Powell was in practice in New York and had not yet joined the faculty at Harvard Law School). Pound suggested to Powell that "If your talk took the line of realism in constitutional law it might do good in an institution where 'the interpretation of a written instrument' has been much insisted upon." 32 As it happened, Pound did not take the advice he gave Powell.

In his three-part series of articles on "The Scope and Purpose of Sociological Jurisprudence," 33 Pound discoursed widely and learnedly on recent European Jurisprudence. As was Pound's wont, the articles ended where another scholar would have begun, with his own vision of contextualist legal theory. "Comparing sociological jurists with jurists of other schools," Pound listed five characteristics of his approach:

1. They look more to the working of the law than to its abstract content: [a pragmatic characteristic]; 2 . They regard law as a social institution which may be improved by intelligent human effort, and hold it their duty to discover the best means of furthering and directing such effort: [part of the Progressive agenda]; 3. They lay stress upon the social purposes which law subserves rather than upon sanction: [another part of the Progressive agenda]; 4. They urge that legal precepts are to be regarded more as guides to results which are socially just and less as inflexible molds: [a second pragmatic characteristic]; 5. Their philosophical views are very diverse....

Pound concluded that "unhappily discussion of general principles goes on and a pragmatist philosophy of law is yet to come. When it is

30. Letter from Pound to Thomas Reed Powell (Mar. 15, 1919) (Pound Papers, 78-6).

31. This was the "pioneering" era of American sociology. A. W. Small founded the first department of sociology at the University of Chicago in 1895 and within ten ycars went on to found the American Sociological Society and the American Journal of Sociology. J. Abraham, "Twentiethcentury Sociology: The Pioneers of the American School," in ORIGINS AND GROWTH OF SocioLOGICAL THEORY: READINGS ON THE HistoRY OF SOCIOLOGY 131, 134-35 (A. Donini \& J. Novack eds. 1982). Abraham also notes that "The beginnings of American sociology, not surprisingly, coincided with that movement in American philosophy known as pragmatism." Id. at 139. He concludes that "early American sociology was imbued with a warm, benevolent, if hazy, kind of idealism. It felt itself involved in the welfare of society, confident in its unbounded optimism that sooner or later the problems of society would be solved. It was part of the business of sociology, it was thought, to prescribe remedies." Id. at 139-40. It is not surprising that with its mixture of Pragmatism and Progressive ideals Roscoe Pound should have sought to ally his view of law with this burgeoning social scientific discipline. See also, P. Buck, Social Sciences at HARVARD, $1860-1920$, at 8-9 (1965).

32. Letter from Pound to Thomas Reed Powell (Mar. 15, 1919) (Pound Papers, 78-6).

33. See supra note 29. 
promulgated it may expect many adherents from the sociological jurists." 34

It was the Pound of "Discontents," "Mechanical Jurisprudence," and "Sociological Jurisprudence" that caught the attention of a bright young associate professor of law at Columbia University, Karl Llewellyn. Llewellyn subsequently adopted Pound as his mentor im jurisprudence. ${ }^{35}$

\section{KARL LLEWELLYN}

In the 1920s, Karl Llewellyn was less well-known than Roscoe Pound among legal scholars. ${ }^{36}$ After World War I, Llewellyn turned down a permanent teaching position at Yale so that he could practice commercial law with the illustrious Wall Street firm of Shearman \& Sterling, where he spent most of his time representing the National City Bank. He was convinced that "the law in the books, at least in the commercial field, was 20 years or so behind the actual work in practice, and I hooked up with the legal work of the National City Bank in the hope of finding out what the law I had been teaching was all about." 37 After three years of practice, Llewellyn returned to Yale as an assistant professor of commercial law. In 1924, he moved to Columbia because his first wife was a graduate student there. ${ }^{38}$

Llewellyn's first major publication, not surprisingly, appeared not in a law review but in the American Economic Review. ${ }^{39}$ In it, Llewellyn advocated reform of commercial law, arguing that the abstract legal principles that dominated late nineteenth- and early twentieth-century coinmercial codes and court decisions hindered modern business. ${ }^{40}$ Llewellyn wanted commercial law to use the insights of economics and modern business practices as guides. ${ }^{41}$ The arguinents in his first article are reminiscent of Pound's comments in 1908. Indeed, Llewellyn pubhicly acknowledged in this article his admiration for Pound and his debt to Pound's Jurisprudence. In the very first footnote, Llewellyn adinitted: "The present paper makes little claim to originality in its details. Much

34. Pound, supra note 29 , at 516 .

35. See infra text accompanying notes $42-48$.

36. For biographical information on Llewellyn see W. TWINING, KARL LLEWELLYN AND THE REALIST MOVEMENT 87-128 (1973).

37. This quotation comes from an autobiographical sketch that Llewellyn apparently prepared for the Yale Law School alumni, probably for the tenth anniversary of their graduation in 1928. Llewellyn Papers, biographical data, red box.

38. W. TWINING supra note 36 , at 102 .

39. Llewellyn, The Effect of Legal Institutions Upon Economics, 15 AM. EcoN. REV. 665 (1925).

40. Id. at 665 .

41. Id. at 672 . 
of the synthesis too, has been indicated by various writers from time to time." He confessed he was "particularly conscious of indebtedness to Sumner, Holmes, Veblen, Commons and Pound."42

In 1925, the same year in which his American Economic Review article was published, Karl Llewellyn, now thirty-two years old and an associate professor at Columbia University School of Law, decided to articulate his general ideas about the new jurisprudence. Like many ambitious younger faculty, he prepared a book proposal for a publisher in the hope of obtaining an advance contract. The book, at least as Llewellyn described it, was neither completed nor published. All that remains is a typescript in the Karl Llewellyn Papers of an outline of chapters and a thirty-three page introductory essay. ${ }^{43}$ That never-published introductory essay is the first expression we have of what Llewellyn ineant by the term "Reahistic Jurisprudence" and what he thought were its intellectual origins. Most interesting, in the light of subsequent events, was the role he first assigned Roscoe Pound in that inovement.

In 1925, Llewellyn unequivocally stated that "[t]he significant school of jurisprudence today is the sociological, of which Dean Pound has been the acknowledged leader and spokesinan." $44 \mathrm{He}$ admiringly proclaimed that "the sociological [school] alone is vital, growing, expanding to ineet new needs." 45 The new thinking, a "multiform mass of efforts," came out of the sociological school. ${ }^{46}$ In analyzing this "new thinking," the only two tenets Llewellyn identified to which nearly every writer in this movement could agree-"that jurisprudence cannot stand alone; and that the significant aspect of law is law's effect"47_appeared in Pound's Jurisprudential agenda from the very beginning. Throughout his "introduction," Llewellyn admitted that most of the breakthroughs and ideas could be traced to Pound. Indeed, Llewellyn called Pound's chapter in the recently published book, The History and Prospects of the Social Sciences, the "best starting place" in the process of describing the new jurisprudential movement. ${ }^{48}$

42. Id. at 665 n.1.

43. Llewellyn, A Realistic Jurisprudence, Llewellyn Papers, B.I.6.a.-c [hereinafter Llewellyn manuscript].

44. Id. at 1.

45. Id.

46. $I d$.

47. Id. at 2.

48. Id. The book was a collection of essays by various authors on all areas of the social sciences published in the same year that Llewellyn wrote his unpublished essay on Realistic Jurisprudence. Pound, Jurisprudence, in THE History and Prospects of THE Social, Sciences 444 (H. Barnes, ed. 1925). 
It is interesting that Llewellyn singled out this obscure essay by Pound as his "starting place" for explaining Realistic Jurisprudence. Neither Llewellyn nor any subsequent scholar of Pound or Legal Realism that I could find thereafter ever cited the piece. ${ }^{49}$ Despite the later obscurity of the collection and Pound's essay in it, in 1925, committed as he was to a social scientific approach to law, Llewellyn's attention was naturally drawn to the newly published book.

Pound's chapter on "Jurisprudence" was, to some extent, a reworked summary of his three-part Harvard Law Review article on Sociological Jurisprudence, but Pound strengthened the programmatic inpact of his own ideas in the later piece by simplifying the intellectual background and stating his own agenda inore forcefully. In writing about the "Sociological School" of Jurisprudence, Pound argued that sociological jurisprudents, including himself of course, shared a common perspective on the law. He claimed that they

look to the working of the law rather than to its abstract content; they regard law as a social institution involving both finding by experience and conscious inaking - an institution which inay be improved by conscious human effort; they lay stress upon the social ends which law subserves rather than upon sanctions; they look on legal precepts and doctrines and institutions functionally and regard the form of legal precepts as a ineans only. Philosophically they are chiefly positivists or neo-realists. They employ a pragmatist method which is consistent with different metaphysical starting points. ${ }^{50}$

That Llewellyn found his views resonating so closely with Pound's is not surprising. All of the characteristics of the sociological jurisprudents that Pound identified in his chapter were characteristics associated with what Llewellyn defined as Realistic Jurisprudence.

In his unpublished essay, Llewellyn quoted the seven points that Pound had claimed to be the "program" of the sociological jurists.

1. Study of the actual social effects of legal institutions and legal doctrines ....

2. Sociological study in preparation for lawinaking.

3. Study of the means of making precepts effective in action.

49. The literature on Pound's jurisprudence is nearly as extensive as the opus of the man himself, but a survey of some of the major studies of Pound, including Grossman, The Legal Philosophy of Roscoe Pound, 44 YALE L.J. 605 (1935); Kreilkamp, Dean Pound and the End of Law, 9 FoRDHAM L. REV. 196 (1940); Morris, Dean Pound's Jurisprudence, in R. SuMmERS, MORE Essays IN Legal Philosophy (1971); D. Wigdor, Roscoe Pound, Philosopher of LAw (1974) shows that they do not cite Pound's 1925 chapter in the Barnes collection. Curiously, Wigdor cites Walter Shepard's chapter in the same volume but never refers to Pound's own essay. Id. at 334 n.29. Wilfrid Rumble's book, supra note 5, at 9-13, connects Pound's sociological jurisprudence to Legal Realism, but his argument would have been even more forceful had he explored Pound's chapter in History and Prospects of the Social Sciences.

50. Pound, supra note 48 , at 458 (emphasis added). 
4. Study of juridical method.

5. A sociological legal history; study of the social background and social effects of legal precepts, legal doctrines, and legal institutions in the past, and of how these effects have been brought about.

6. Recognition of the importance of individualized application of legal precepts.

7. In English-speaking countries [sic], a ministry of justice..$^{51}$

These seven points were similar, but not identical, to the characteristics Pound had earlier described in "Sociological Jurisprudence."52 Llewellyn conceded: "The first, third, fourth and fifth of these points may well be found to cover the bulk of the present paper . . .."53 In fine, Llewellyn's view of Realistic Jurisprudence almost totally coincided with Pound's description of Sociological Jurisprudence, though Llewellyn argued that the "differences in emphasis become significant enough to warrant continuing." 54 The primary difference in emphasis, Llewellyn contended through the next several pages, was Pound's integration (or confusion) of ethics, morahty, or prescriptive ideals with juristic science. Llewellyn noted that "[i]t is hard to see how a movement for anything but discovery of objectively verifiable facts and relations between facts can be characteristic of any science."5s To the extent that Pound and others had characterized Jurisprudence as a science, therefore, Llewellyn retorted that it was an error to study what "is" and what "ought" to be as one enterprise. ${ }^{56}$

Llewellyn had already criticized Pound's unscientific analysis of the relationship of Law and Morals in a Yale Law Journal review of Pound's published McNair Lectures. ${ }^{57}$ Llewellyn took Pound to task: "what the author means by morals, and the genesis and working of such morals as agencies of social control, are passed over in silence."58 Llewellyn's frustration with Pound's analysis was not unjustfied. After a detailed historical treatment of various Jurisprudents' views, Pound had concluded:

In general law cannot depart far from ethical custom nor lag far behind it. For law does not enforce itself. Its machinery must be set in motion and kept in motion and guided in its motion by individual human beings; and there must be something more than the abstract 63.

51. Id. Llewellyn quoted the list of points directly from Pound's chapter, supra note 48 at 462 -

52. See supra text accompanying note 34 .

53. Llewellyn Manuscript, supra note 43 , at 2.

54. Id.

55. Id. at 3.

56. Id. at 3-4.

57. Llewellyn, Book Review, 34 YALE L.J. 113 (1924) (reviewing R. Pound, LAW AND MORALS (1924)).

58. Id. at 113. John Dewey similarly criticized Pound in his review of Law and Morals. Dewey, Book Review, 25 Colum. L. Rev. 245, 246 (1925). 
content of the legal precept to move these human beings to act and to direct their action. 59

In the very next sentences, however, Pound retreated from this "realistic" evaluation. Pound stated:

Yet one need but look at a mass of legal precepts that make up the bulk of legal systems today in order to see that they are anything but authoritative promulgations of ethical custom. For the most part they represent juristic or judicial search for a rule that will follow logically from the traditional legal materials, or for a rule that may be said to have authority behind it. They are techmical workings over of the traditional precepts, or techmical adaptations of authoritative extralegal propositions. They are the technical, scientific custom of the courts and lawyers. ${ }^{60}$

It is not hard to see how Pound's contradictory statements about law as ethical miperative and law as juristic technique might have led Llewellyn to conclude that "the mterest and value of the lectures do not lie in the light they shed upon their titular subject."61

Despite Llewellyn's reservations about Pound's views on the relationship of juristic science and morals, Llewellyn, in his "Realistic Jurisprudence" manuscript, confessed that

[d] espite these difficulties, the road again seems open. The sociological school, in shifting emphasis from rule and precept to the effect of law, have taken us out of a study of words into a study of deeds, have shifted our focus from the point where "ought" imtrudes inost insidiously to the point where "is" stands observable by any who will look. Under this new emphasis the correspondence of observed data to reality acquires some pragmatic guaranty. ${ }^{62}$

The conclusion reached by Llewellyn echoes that reached by Pound in "Sociological Jurisprudence" and his chapter in The History and Prospects of the Social Sciences in its call for a pragmatic jurisprudential approach. Thus, although Llewellyn would temporarily divorce the Pragmatic from the Progressive, he acknowledged his Realistic approach was but a plantlike "shoot" off the "vital" "stock" of Pound's Sociological Jurisprudence. 63

59. R. POUND, LAW ANd Morals 122 (1924).

60. Id. at 122-23.

61. Llewellyn, supra note 57 , at 113 .

62. Llewellyn Manuscript, supra note 43 , at 5-6.

63. Id. at 1 . 


\section{Llewellyn's EXClusion of POUND}

Let's jump forward in time, just a bit. Elsewhere I have described in some detail the famous 1930-1931 "debate" between Karl Llewellyn and Roscoe Pound. ${ }^{64}$ I will only briefly outline that debate here.

Near the end of 1930, Llewellyn finally went into print with his jurisprudential ideas in a Columbia Law Review article entitled, "A Realistic Jurisprudence-The Next Step."65 Although he acknowledged the leadership of Pound in modern Jurisprudence generally, he was nevertheless both highly critical of Pound's views and downplayed, without explicitly denying, any direct link between the "Realistic" Jurisprudence that he promoted, and the sociological scliool of Jurisprudence advocated by Pound. In March, 1931, Pound responded, to Llewellyn's article and Jerome Frank's Law and the Modern Mind, ${ }^{66}$ in a Harvard Law Review article entitled "The Call for a Realist Jurisprudence." 67 Pound cominended the Realist moveinent in a general way. Indeed, Pound was essentially the first person to acknowledge that there was an actual "movement" im place. At the saine time, he identified serious flaws and fallacies in soine of the Realist autliors' scholarly work, although he failed to cite a single specific book, article, or author to support his criticism.

Llewellyn responded almost viscerally to Pound's article. With the aid of Jerome Frank ${ }^{68}$ he wrote a second article entitled "Some Realism About Realism-A Reply to Dean Pound," which was published in the Harvard Law Review only three months after Pound's essay. ${ }^{69}$ In this latter piece-now considered a classic of jurisprudential literature and the definitive statement about the early Realist movement-Llewellyn identified twenty-two Realists whose work he would survey in order to refute Pound's critique. ${ }^{70}$ In doing this, Llewellyn effectively defined the boundaries of the new legal thought and categorized all inodern legal

64. Hull, supra note 3 .

65. Llewellyn, Next Step, supra note 3.

66. J. FRANK, LAW AND THE MODERN MIND (1930).

67. Pound, supra note 3.

68. The Llewellyn-Frank alliance was predictably short-lived; their falling out in the early 1940s was inevitable. Jerome Frank's "Realism" was distinctly different from Llewellyn's. Indeed, while I argue that Llewellyn was a genuine Realist, Frank, with his view of the extreme subjectivity of legal facts, his "fact-skepticism," was what we would now call an "Anti-Realist." Compare Frank with the post-structuralists, supra note 7. Thus I will argue in my book that although Llewellyn remained fond of and continued to admire Frank's emphasis on trial courts, he finally recognized how much closer he was to Pound than Frank in the Jurisprudential universe. N. Hull, Pound AND LLEWELLYN: CONSENSUS AND CONFLICT IN THE FORMATIVE ERA OF AMERICAN JURISPRUDENCE, 1902-1962 (forthcoming).

69. Llewellyn, Reply, supra note 3.

70. Id. at 1257-59. 
theorists as either belonging to the movement or opposing it: one was either part of the modern trend in jurisprudence or one of the old-style thinkers.

In coinpiling his hist of the "ins," Llewellyn consulted many of the theorists he admired on the question of who ought to be considered a "realist."71 At least two of his correspondents logically enough suggested that he include Pound himself. They recognized the role Pound had played in the development and practice of the new thought and proposed that including Pound would deflate his critique. ${ }^{72}$ One of these men advised Llewellyn, correctly I think, that Pound wanted to be identified with the new legal thought, and if Pound was peeved at all with some of the recent hiterature, it was because he had been isolated from rather than acknowledged as part of the newer movement. ${ }^{73}$

Llewellyn responded negatively to these suggestions to include Pound. He repeatedly refused to add Pound to his list, ostensibly because Pound liad written too inuch to survey in the short time Llewellyn liad to get out the response-or at least that is what he told his colleagues. ${ }^{74}$ In fact, Llewellyn's objections ran deeper. In a draft footnote that was not included in the pubhished article-again extant ouly as a typescript in Llewellyn's papers-Llewellyn outlined the intellectual history of the "newer legal thinking," an intellectual history that explicitly demied any connection or debt to Pound and his sociological jurisprudence. ${ }^{75}$ Llewellyn empliatically argued: "None [of the new legal thinkers] draws in any important measure on Pound. Rather, already set in their views, did they go back over Pound's work critically, accepting here, rejecting there, in the hight of their own thinking."76

During the six years between Llewellyn's acknowledgment of Pound's inspiration of the Realist movement and the Harvard Law Review debate, Llewellyn completely reconceptuahized the intellectual pedigree of "Reahistic Jurisprudence," banishing Pound from the central place in its development and sending liim into exile from jurisprudential reforin. Why? What had liappened in the intervening years to so alienate Llewellyn from Pound's Jurisprudence? Why did Llewellyn feel he liad to divorce liimself and his movement from the eminent Harvard

71. Memorandum sent to several addressees (Mar. 27, 1931) (Llewellyn Papers, B.65(b)).

72. Letter from Charles E. Clark to Llewellyn (Mar. 31, 1931); Letter from Joseph Walter Bingham to Llewellyn (Apr. 7, 1931), (Llewellyn Papers, A.II.65(b)).

73. Letter from Joseph Walker Bingham to Llewellyn, (Aug. 10, 1931) (Llewellyn Papers, A.II.65(b)).

74. Letters from Llewellyn to Joseph Walker Bingham (Apr. 13, 1931 and Aug. 31, 1931) (Llewellyn Papers, A.II.65(b)).

75. Proposed Footnote to Article in Reply to Pound, in Llewellyn Papers, A.II.6.(b).

76. Id. at 3 . 
dean who had earher played such an important role in Llewellyn's ideas about jurisprudential reform?

\section{Causes of the Estrangement}

Two mcidents durmg those crucial years help explain Llewellyn's increasing estrangeinent froin Pound's Jurisprudence: Llewellyn's and Pound's respective roles in the Sacco and Vanzetti appeals in 1927, and the further intellectual and personal schisin between Llewellyn and Pound over an article about contract law they were supposed to write together for the Encyclopedia of the Social Sciences. Though the one was a celebrated criminal case and the other an obscure event, they reinforced in Llewellyn's inind Pound's politic caution-a trait Llewellyn neither shared nor understood. Moreover, events during their collaboration caused a personal breach between the two inen that had direct jurisprudential repercussions.

\section{A. The Sacco and Vanzetti Affair}

In 1925, just as Llewellyn penned his book prospectus and published in American Economic Review his article lauding Pound's Sociological Jurisprudence, Roscoe Pound quietly involved himself in the national furor over the conviction and condemnation in Massachusetts of Nicola Sacco and Bartolomeo Vanzetti. The cobbler and the fish monger were leaders in a post-war anarchist workers inovement. Both men were accused and convicted of a payroll robbery and murder of a guard. The case had drawn widespread attention because substantial questions had been raised about the fairness of the proceedings: were the two radical immigrants found guilty of the crime charged, or had they been prosecuted and condemned for who they were and what they represented? The resulting furor among thoughtful citizens and intellectual leaders grew to such a pitch in the mid-1920s that few in public life or academia could remain neutral in the debate. Like the Dreyfus affair less than a half-century before in France and the McCarthy hearings a half-century later in the United States, the Sacco and Vanzetti case became a passionate cause célebre for educated Americans. If a miscarriage of justice was being perpetrated in Massachusetts, then the American system of justice stood trial. That law professors would be drawn into the debate should surprise no one. Who else could better evaluate the judicial proceedings 
and advise the public on their legality? Who had greater expertise or interest in the fundamental structure of American justice?77

Conventional accounts of the Sacco and Vanzetti case tell us that Harvard law professor Felix Frankfurter was the first legal academic to involve himself as adviser to defendants' counsel. ${ }^{78}$ In fact, Frankfurter was not the first Harvard academic to write to William Thompson, Sacco and Vanzetti counsel in their appeals, or to critically comment on the legal proceedings. On May 9, 1925, nearly two years before Frankfurter's published defense of Sacco and Vanzetti in the Atlantic Monthly, ${ }^{79}$ Roscoe Pound contacted Thompson to suggest a line of attack on the identification evidence presented at the anarchists' trial. ${ }^{80} \mathrm{~A}$ month and a half later, the Harvard dean wrote again to Thompson with a more forceful expression of his opinion of the case: "At the time of the ... trial I read the testimony from day to day in the newspapers, and had a very strong feeling that I would not hang a dog on the evidence." $81 \mathrm{He}$ also told Thompson that he was "convinced that the whole trial ought to be written up thoroughly," but he personally demurred from the job since "just at the moment it would be quite inupossible for me to do so." He regretted that his hectic schedule kept him from taking on the task because, he told Thompson, "I feel strongly that somebody ought to have the courage and the sense of justice to speak out vigorously about these cases." 82

As strongly as he may have felt about the injustice, Pound did not want to speak out. He recounted to Thompson the problems that had plagued his colleague Zecharialı Chafee, Jr., when Chafee publicly criticized the Abrams free speech case during the red persecutions of $1920 .{ }^{83}$ Chafee nearly lost his position when conservative Harvard alumni scored the law professor's support of the radical New Yorkers. Pound hinself may have felt some heat since Chafee had convinced the dean to sign the Abrams petition as well. Pound had stood by Chafee, defending him and saving his job. In comparison to the Chafee Abrams episode, local feeling on the Sacco and Vanzetti cases was so much more charged that

77. The two best books about the case are L. Joughin \& E. MORGAN, THE LEGACY OF SACCO and Vanzetti (1948) and W. Young \& D. Kaiser, Postmortem: New Evidence in the CASE OF SACCO AND VANZETTI (1985).

78. W. Young \& D. KAISER, supra note 77, at 5-6.

79. Frankfurter, Case of Sacco and Vanzetti, 1927 ATLANTic MONTHLY 409.

80. Letter from Pound to Thompson (May 9, 1925) (Pound Papers, 33-44).

81. Letter from Pound to Thompson (June 28, 1925) (Pound Papers, 33-24).

82. Id.

83. On Chafee's role in the Abrams case, see R. POLENBERG, Fighting FAITHS: THE Abrams Case, The Supreme Court, and Free Speech 272-84 (1987); D. SMItr, Zechariah ChafeE, JR.: DEFENDER OF LIBERTY AND LAW 36-57 (1986). 
Pound certainly would have jeopardized his deanship if he had gone public with his condemnation of the proceedings.

In the spring of 1927, after Judge Webster Thayer sentenced the men to death, supporters of Sacco and Vanzetti stepped up their public appeals and their attacks on the fairness of the proceedings. Pound never did find the time to challenge the mjustice of the trial, but the law school community was directly drawn into the furor when Felix Frankfurter's strongly-worded assault on the legal proceedings appeared in the March issue of the venerable, Boston-based Atlantic Monthly. The conservative supporters of the verdict found their champion in the same criminal law and evidence expert who had supported the conviction of the Abrams defendants: former Northwestern University Law School dean, John Henry Wigmore. ${ }^{84}$ Wigmore's intemperate article attacking Frankfurter and praismg Judge Thayer and the legal system of Massachusetts enraged hiberal legal academics. ${ }^{85}$ Even his old friend and protege Roscoe Pound was incensed by Wigmore's attack on Frankfurter. Privately, Pound wrote to a law school alumnus that "Wigmore ought to be shown up in this niatter ... [his Boston Evening Transcript] letters are a disgrace to legal scholarship."86 Yet again Pound would not publicly take up Frankfurter's defense. Pound confided that he "had thought seriously (when the smoke of controversy had cleared away a bit, and reason on this subject had ceased to be inhibited) of writing the matter up myself ... [but] I do not see any reason why, after the careful, scientific review of the matter which I know you would make, you should not speak out in meeting your conclusions." 87 But Pound hilnself would not speak out or publicly take a stance in defense of Sacco and Vanzetti or meet head on Wigmore's attack on Pound's own colleague.

Contrary to accounts by Pound's biographers, however, ${ }^{88}$ Pound did enter the public debate about the Sacco and Vanzetti case. He wrote

84. On Wigmore's attack on Holmes's dissent (Brandeis concurring) in Abrams, see R. POLENBerg, supra note 83, at 248-56.

85. Wigmore, J.H. Wigmore Answers Frankfurter Attack on Sacco-Vanzetii Verdict, Boston Evening Transcript, Apr. 25, 1927, at 1, 12, col. 5 (available in Wigmore Papers, Northwestern University Library). Frankfurter replied to Wigmore the next day in the same newspaper and then Wigmore responded in a second article in the Boston Evening Transcript. Wigmore, Wigmore Replies to Frankfurter in Sacco-Vanzetti Controversy, Boston Evening Transcript, May 10, 1927, at 14, col. 3 (available in Wigmore Papers, labeled as $B$ Herald).

86. Letter from Pound to Eustace Seligman (May 23, 1927) (Pound Papers, 32-14).

87. Id.

88. Neither of Pound's biographers appear to be aware of Pound's advice and correspondence with the defendant's counsel on appeal, William Thompson, the Pound petition calling for an independent panel to review clemency for Sacco and Vanzetti or his letter to the editor about the pardon process. The letter is quoted in L. Joughin AND E. MoRGAN, supra note 77 at 302 . Morgan was Pound's colleague at Harvard. While the discussion, infra note 106, agrees that Pound's public expressions were carefully neutral about the case, nevertheless his public statements could be 
and promoted a petition to Governor Fuller that called for " ' a disinterested board . . . in whom the people have confidence' to report to the "Governor their findings of fact, their opinions and their conclusions." "89 But Pound's petition explicitly stated that it was "not intended as an expression of our opinion on the question of the guilt or innocence of Sacco and Vanzetti now under sentence of death, or on the questions of the fairness of their trial or the justice accorded them." 90 Pound's petition was meticulously neutral; it displayed not a hint of his true opinion of the matter. If he had taken a stronger, more partisan stand, such a public declaration by the preeminent law school dean in the country might have had an enormous impact on the outcome of the appeal. Though he felt very strongly about the case, Pound nevertheless refrained from using his prestige to aid the two men. He earlier had excused himself from public comment by arguing that it was improper to criticize a case while it was still on appeal before the courts; by late April that was no longer the case. Pound knew that Frankfurter's mvolvement had brought the law school imto controversy and any partisanship on the dean's part would have caused serious damage to the school's relationship to the Massachusetts legal community.

Llewellyn, a mere associate professor at Columbia University School of Law in New York, was either far less vulnerable to assault for public advocacy of Sacco and Vanzetti, or far more vulnerable, since his promotion to full professor, coincidentally processed that same spring, might have been jeopardized by lins involvement in the hotly debated case. Llewellyn did not weigh his vulnerability. He charged into the crusade for the condemned radicals regardless of consequences. Perhaps dissatisfied with the inadequacy of Pound's petition, Llewellyn agreed to spearhead an American Civil Liberties Union (ACLU) campaign to organize the nation's law professors in support of the defendants' appeal. After Vanzetti applied to Massachusetts Governor Alvin Fuller for clemency in early May, 1927, Llewellyn orgamized his own law professors's petition for Vanzetti on legal grounds. ${ }^{91}$ Llewellyn and the ACLU probably hoped that if an overwhelming number of the nation's law professors publicly expressed their doubt that the trial passed procedural muster,

and probably were construed as supporting the convicted men. Wigdor explicitly denies that Pound ever engaged in the public debate. D. WIGDOR, supra note 15, at 249-50. Sayre simply never mentions any public activity by Pound and by apologizing for Pound he implicitly suggests he stayed out of the public debate. P. SAYre, supra note 15, at 219-23.

89. Undated and unattributed newspaper clipping found in Llewellyn Papers, G.II.(S-V) (Green Box). A brief summary of the petition appears in Says Judge Thayer Did Confuse Issue, N.Y. Times, April 27, 1927, at 16, col. 6.

90. Id.

91. For Llewellyn's role in the Sacco-Vanzetti affair, see Llewellyn Papers G.II. (Green Box). 
Fuller would have to appoint an independent panel that might recommend clemency and the men would be saved.

Llewellyn's petition barely avoided advocacy, asserting that only a review by an impartial body can determine whether the widely held belief is true that two issues had been confused in the murder trial-the radicalism of the defendants and their guilt or innocence of the murder .... [T] he fact there is widespread doubt as to the justice of the result lends color to the possibility that such mistake may have been committed." 92

In other words, Llewellyn, while ostensibly protecting the neutrality of the professors on the merits of the case, actually allied them with those who condemned the proceedings.

With the scheduled execution date only one month away, Llewellyn telegraphed every legal acadeinic he knew and every major law school in the country to obtain signatories for his petition..$^{93}$ Sixty-one law professors from twelve law schools signed or authorized acquiescence in Llewellyn's petition. ${ }^{94}$ All but two of Llewellyn's own colleagues joined him. Interestingly, some of the signatories apparently first made his acquaintance through the petition. ${ }^{95}$ Indeed, quite a few of the Realists on both Llewellyn's published and unpublished lists responded favorably to Llewellyn's appeal and signed the petition, ${ }^{96}$ although several of them were not active jurisprudents and the label of Realist was never otherwise applied to them. ${ }^{97}$

It seems probable that Llewellyn's view of who were the jurisprudentially enlightened was to some extent influenced by their support for Sacco and Vanzetti. Witlout specifically mentioning the Sacco and Vanzetti episode as a criterion for identifying the Realists, Llewellyn much later confided to a friend that "lie doubted there was any significant con-

92. Professors of Law Urge Sacco Inquiry, N.Y. Times, May 10, 1927, at 9, col. 1 [hereinafter Professors].

93. Copies of Llewellyn's telegram and many of the telegraphed responses are in the Sacco and Vanzetti material, Llewellyn Papers G.II (Green Box).

94. Professors, supra note 92.

95. See, for example, telegrams from Joseph Francis and Max Radin that indicate that they were not previously acquainted with Llewellyn, Llewellyn Papers G.II. (Green Box).

96. Eleven of the twenty-two individuals listed as Realists in Llewellyn, Reply, supra note 3, signed the petition: Underhill Moore, Herman Oliphant, Edwin Patterson, Hessel Yntema, Joseph W. Bingham, L.A. Tulin, Walter Wheeler Cook, Ernest Lorenzen, Charles E. Clark, and Joseph F. Francis (as well as Llewellyn himself). Id. at 1257-59. Four additional law professors whom Llewellyn included on the longer list of Realists that he sent to Pound, but omitted from the published article, also signed the petition: Young B. Smith, Alexander M. Kidd, Richard R. Powell and Robert Maynard Hutchins. See Hull, supra note 3, at 969.

97. For example, Young B. Smith, Robert Maynard Hutchins, Richard R. Powell and Alexander M. Kidd. Comparison of petitiou published in Professors, supra note 92, to list sent to Pound (published in Hull, supra note 3, at 969). 
nection between the juristic and political views of Realists, except that some, but by no means all, who wanted reform within the field of law were also interested in political reform." 98 Despite his own demal that politics was the intellectual impetus for the so-called Realists, Llewellyn disingenuously suggested that "Pound's dislike of Reahsm may have been politically motivated." 99 Notably absent from those signing or authorizing support for the Llewellyn-ACLU petition were any members of the Harvard Law School faculty, mcluding Roscoe Pound.

Pound's calculated neutrality in his petition to Governor Fuller may have been a pragmatic strategy. Perhaps Pound thouglit that his enormous reputation and professed public neutrality on the merits would lead Fuller to appoint the Harvard dean himself to this independent paneland if so, Pound could do the two condemned men greater service as an official advisor to the governor than as an outspoken, but officially powerless, public advocate. Pound's description of the qualifications for the men Fuller should choose supports such an interpretation. Pound recommended that the "disinterested board ... be composed of lawyers and laymen of standing in whom the people have confidence."100 There was probably no lawyer in Massachusetts at that time who had greater standing with the thouglitful public than Pound, and he had demonstrated his disinterestedness. Pound, however, was not chosen for the panel.

Governor Fuller, under increasing pressure by law professors and others, finally appointed an "independent" advisory committee on June 1, 1927. Instead of choosing the law school dean, Governor Fuller appointed Harvard Umiversity President A. Lawrence Lowell to chair the "independent" panel to review the Sacco and Vanzetti case. ${ }^{101}$ Lowell, however, came to the panel predisposed to condemn the two men. Pound and Lowell had been friends and allies in the Chafee affair; ${ }^{102}$ they respected one another. Lowell had actually confided to Pound, before the former had been appointed to chair the commission, "that he did not care whether they [Sacco and Vanzetti] were guilty or not, public confidence in the institutions of Massachusetts required that the sentence be carried out."103 In a letter to former U.S. Senator and ABA President Chester Long in which Pound reported Lowell's comments, Pound indi-

98. William Twining paraphrasing letter from Llewellyn to G.B.J. Hughes (August 10, 1954) (Llewellyn Papers, R. VIII, 17, at 522 n.7).

99. Id.

100. $I d$.

101. See L. Joughin And E. Morgan, supra note 77 , at 298, 301, $302-04$.

102. See R. Polenderg, supra note 83, at 281.

103. Pound did not identify who among the panel had expressed these views, but it is a reasonable inference that only Lowell had a close enough relationship to Pound to have made such a confidence. Letter from Pound to Chester I. Long (Aug. 6, 1927) (Pound Papers, 24-9). 
cated that he might go public with this information before the American Bar Association Executive Committee "should it become necessary to discuss [the Lowell Commission's] report," although he admitted "I hope it will not [be necessary] until things have cooled off a bit . . ." 104 Despite his own certain knowledge of Lowell's bias, Pound never publicly spoke out against the governor or his commission, even though such damning testimony might have impeached the Commission's report and created a public furor that could have saved the two men's lives. Privately, Pound continued to express his personal reservations about the case to almost anyone who wrote to him about the affair. ${ }^{105}$ While he encouraged his correspondents to write to newspapers expressing their own views, the dean resolutely refused to have his own stand publicly disseminated. ${ }^{106}$ His only other public comment was another neutrallyworded, scholarly letter to the Boston Herald on June, 1927, that discussed "petitions for pardon and the relation of the exercise of the pardoning power to the admmistration of justice by the courts." 107

Pound's failure to commit himself publicly in defense of Sacco and Vanzetti contrasted sharply with Llewellyn's own approach. Llewellyn abandoned even the semblance of academic neutrality after Governor Fuller's commission affirmed Thayer's death sentence. On the eve of the two men's execution, Llewellyn delivered an impassioned radio address condemning Governor Fuller, Judge Thayer, and the Massachusetts appellate process. ${ }^{108}$ Indeed, Llewellyn's interest in the case did not diminish even after the execution. He joined the executive committee of the Sacco and Vanzetti National League, the successor to the Defense Committee, and began work on a book for the League that would presumably

104. Id.

105. See numerous letters in Pound Papers, 24-9, 34-14.

106. Pound wrote favorably to Richard Washburn Child complimenting him on a manuscript about the case and expressed his views that

Instead of seeking to maintain a temporary confidence in our criminal justice by upholding the conviction at all hazards, the profession ought to be concerned with the right and justice of the cause, reflecting that the ultimate effect on confidence in our criminal courts will be the more serious should a factitious, temporarily-built-up confidence will fail us.

Letter from Pound to Richard Washburn Child (Jan. 3, 1927) (Pound Papers, 23-18). But when Child wanted to quote Pound in the published version of the article, the dean hastily wrote Walter Lippman, editor at the World, that when he wrote to Child he "was not writing for publication." Letter from Pound to Walter Lippman (Jan. 26, 1927) (Pound Papers, 23-18).

107. Pound's letter appeared in the Boston Herald, June 4, 1927. The description of Pound's letter comes from a letter of appreciation from Reverend Edward C. Camp, Pastor of the Phillips Congregational Church in Watertown, Mass. to Pound written on the day Pound's Boston Herald letter was published. Letter from Edward C. Camp to Pound (June 4, 1927) (Pound Papers, 32-14).

108. Llewellyn, Remarks on the Sacco-Vanzetti Case, (Aug. 20, 1927) (speech delivered at WPCH, New York City, reprinted in W. TwiNING, The KARL LLEWELlYN PAPERS 105-10 (1968). 
vindicate the dead men.109 Pound, even after the furor had died down, only encouraged others to protest the injustice of the case and continued to remain neutral in public. ${ }^{110}$

109. The manuscript for Llewellyn's contribution to the Sacco and Vanzetti book as well as the correspondence with the Sacco and Vanzetti League, the other contributors and the publisher are all contained in Llewellyn Papers, G.II. (S-V) (Green Box).

110. See, for instance, Pound's correspondence with Henry Edgerton and Charles Cuip Burlingham in the fall of 1927 (Pound Papers, 32-14).

Pound alienated his longtime ally Felix Frankfurter and other liberal members of his law facuity in an in-house postscript to the case. The Fall following the Sacco and Vanzetti executions, two law school faculty appointments ran afoul of President Lowell. In both cases, the president was probably using the appointments as surrogates for his anger at his Sacco and Vanzetti nemesis, Felix Frankfurter. A young Jewish assistant professor of law, Nathan Margold, came up for a vote for a permanent position. The law facuity, including Pound, voted overwhelmingly to approve the Margold appointment, but President Lowell vetoed the faculty's recommendation. The faculty suspected Pound "was not as enthusiastic about Margold in his private discussions with Lowell as he was in front of his colleagues." When Frankfurter, Edmund M. Morgan and T.R. Powell tried to move to resubmit the appointment, Pound opposed the motion. Pound did not carry the law professors' banner. He acquiesced in Margold's rejection and frustrated Frankfurter and his allies. Pound's reasons are understandable if not laudable. Margold was a reasonably strong candidate by law school standards, but he was, by no means, a rising star of legal scholarship. Lowell may have unfairly rejected the appointment, but Pound didn't see the merits of Margold's case as strong enough to jeopardize his deanship. And, of course, to openly challenge the president of the university on an faculty appointment decision was doomed to failure. The likely result would then be that Pound would be forced to resigu. If he wavered over taking such a step for Frankfurter, then it was ridiculous to expect him to take such a suicidal move for Margold. And for Pound, being forced to give up the deanship would have been a kind of suicide. Being dean of Harvard Law School was the position for which he had striven throughout his career. Though tempted with important judicial appointments and actually being offered the presidency of the University of Wisconsin, he turned them all down to remain dean. Now Frankfurter and the liberal faculty expected him to sacrifice his deanship for a lowly, and not terribly promising assistant professor-for Pound, it was unthinkable.

Later that year, another dispute erupted with Lowell when the president disregarded the faculty's unanimous support of Frankfurter's protege, James M. Landis as professor of legislation. Again, the faculty was unhappy with Pound's advocacy of their position when the dean sought a compromise with Lowell, rather than fighting Lowell on the matter. Pound's actions in the Margold and Landis appointments were not popular with Frankfurter and his friends. The independence and honor of the faculty was at stake. Pound had failed to vigorously support them in the face of a flagrant and prejudiced attack by the autocratic university president. He had allied himself with conservative forces, and word spread through the legal academic community: Pound was a trimmer, indeed, not a reformer, not a member of the hiberal, new-thinking vanguard, but a supporter of the status-quo old guard. And if he was one of them now, perhaps he always had been. All in all, Pound's role in the Sacco and Vanzetti case and its aftermath helped to isolate him from his Jurisprudential heirs, because a liberal viewpoint was one index of the reformist Jurisprudence.

See L. Kalman, Legal RealisM AT YALE, 1927-1960, at 58-61 (1986). Kalman recognizes the fact that Pound's difficulties with Frankfurter stemmed from his "appeasement of President Lowell in the 1920s," and that Lowell had been Frankfurter's nemesis at least since 1927, as a result of their contrary positions on the Sacco and Vanzetti case, but she does not directly connect Lowell's actions on the Margold and Landis appointments-in the very Fall after the executions-to his antagonism for Frankfurter. Like Kalman, Wigdor attributes the rift between Pound and his faculty to the Margold appointment but does not see the connection to the Sacco and Vanzetti case; it is simply a question of Lowell's anti-semitism. D. WIGDOR, supra note 10, at 251. 
It is important to understand that Pound's position was allied in spirit to the liberals who supported Sacco and Vanzetti, even if he did not stand shoulder to shoulder with them in the public arena. He had not yet associated himself with political conservatives, not in 1927, but the liberal-progressive rabble rouser who had excoriated the ABA in 1906, publicly condemned the U.S. Attorney General for the red persecutions of 1920, and defended Zechariah Chafee and the Abrams defendants in 1921, now shrank from publicly avowing his private convictions. This case was too close to home, in his own backyard as it were. To openly broadcast his position would antagonize the Massachusetts bar, law school alumm, and most importantly, the president of his university at whose pleasure he served as dean. Pound's failure was not a failure of liberal sentiment, but rather a failure of courage and integrity. Nevertheless, as a result of this lapse, Pound's reputation as a liberal, a reformer, and the mentor of the new jurisprudential thinkers stood in jeopardy.

Llewellyn's view of Pound probably was influenced by the Sacco and Vanzetti affair and its aftermath, an attitude reflected in Llewellyn's attack on Pound's later scholarship in his first Realism article. The attack was focused, however, only on the later Pound (apparently corrupted by his experience as dean). Llewellyn's first Realism article still acknowledged Pound's early preeminence and infiuence. ${ }^{111}$

Pound's reaction to Llewellyn's original attack had been friendly. Pound indicated that he had taken no offense from Llewellyn's somewhat harsh evaluation of his recent work. Indeed, Pound wrote Llewellyn a congratulatory note. ${ }^{12} \mathrm{He}$ even admitted that his recent writings may not have been up to snuff: "May you be spared the necessity of making bar association addresses and popular talks which falls to the lot of a voice crying in the wilderness as mine had to be so long. Very likely it got injured in the process." $113 \mathrm{He}$ even applauded Llewellyn and the other younger scholars who he obviously felt were following in his footsteps. He told Llewellyn that "better things are at hand with the oncoming generation. Veni fortior me post me."114 Llewellyn was surprised but delighted by Pound's graciousness. Perhaps he thought the old boy was not entirely lost to the Jurisprudential reformers, though he had lately shown some conservative tendencies. Llewellyn urged the pioneering Progressive-Pragmatist to "pry loose leisure to show us what skilled irrigation can do to a wilderness." 115 The two men were at least

111. Llewellyn, Next Step, supra note 3, at 433-35.

112. Letter from Pound to Llewellyn (April 29, 1930) (Llewellyn Papers, R.XVI.5).

113. Id.

114. Id.

115. Letter from Llewellyn to Pound, May 1, 1930 (Pound Papers, 24-6). 
partly reconciled and Llewellyn still accepted the older jurisprudent as a part of the original reformist movement.

\section{B. The Llewellyn-Pound Collaboration}

About eight months after this exchange of pleasantries, Alvin Johnson, managing editor of the Encyclopedia of the Social Sciences project, wrote Roscoe Pound, his editorial advisor on law and frequent contributor, that "we are in a considerable jam over our article on Contract."116 Sometime before, Johnson had asked Pound to write a major piece on contract law for the Encyclopedia. ${ }^{117}$ Pound already had contributed several articles, including those on Jurisprudence and the American Law Institute. But this time Pound had to turn Johnson down. The press of his duties as dean and his work on the Wickersham Commission, made taking on another scholarly project-for-hire, even for the "handsome" standard rate of $\$ 20$ (per article), ${ }^{118}$ impossible. Rebuffed by Pound, Johnson decided to ask the rising star of commercial law, Karl Llewellyn, to take on the task. Pound may have recommended Llewellyn himself, or Johnson might simply have looked up who was teaching contracts on the Columbia campus, ${ }^{119}$ or Llewellyn might have been suggested by either Arthur Corbin or Samuel Williston-the two acknowledged giants of contract law at that time. It is possible that Johnson first approached either or both of these men to write the piece, but they both were engaged just then im the monumental American Law Institute Restatement project. Corbin had been Llewellyn's mentor at Yale, and Llewellyn fondly called him "Dad."120 Samuel Williston, the grand old man of Contracts at Harvard, Langdell's chosen successor, was also familiar with and apparently fond of the brash young contracts reformer. ${ }^{121}$

116. Letter from Alvin Johnson to Pound (January 12, 1931) (Pound Papers, 13-9).

117. Johnson refers to the earlier solicitation and Pound's response in a later letter from Alvin Johnson to Pound (Jan. 12, 1931) (Pound Papers, 13-9).

118. See Letter from Alvin Johnson to Pound (Aug. 13, 1929) (Pound Papers, 13-9) (thanking Pound for two of these articles and mentioning enclosure of a check for $\$ 20$ for the ALI piece).

119. The Encyclopedia project was headquartered in Fayerweather Hall, across a campus archway from the Columbia Law School.

120. See Corbin-Llewellyn correspondence, Llewellyn Papers, R.III.15.

121. This is not the place to go into the relationship between Llewellyn and Williston, though I hope someday to write an article reevaluating Williston in which the Llewellyn-Williston correspondence will figure. Briefly, Williston's correspondence with Llewellyn began when Llewellyn reviewed Williston's treatise on contracts in 1925. Llewellyn, Book Review, 34 YALE L.J. 454 (1925) (reviewing S. WILliston, CoNTRACTS (1925)). Williston wrote to Llewellyn thanking him for his kind words and also to start a friendly exchange over some mild criticisms Llewellyn had made. Williston told Llewellyn, that basically he agreed with the younger man, and admired the Columbia professor's work. Letter from Samuel Williston to Llewellyn (Feb. 16, 1925) (Llewellyn Papers, 
However Llewellyn came to Johnson's attention, the former submitted his 7414 word article (the assignment asked for only 5000 words) on "Contract" to Johnson in early December, 1930. ${ }^{122}$ Johnson's problem was not with the length of the piece; rather, he told Pound that Llewellyn "treated the subject dynamically but impressionistically. It seems to us that while his article is excellent as far as it goes, it is weak in its historical and comparative aspects." 123 In other words, Llewellyn had written a Realistic article on contract law rather than a conventional survey of the field. ${ }^{124}$

Llewellyn attempted, in this encyclopedia article, to convey the cultural and economic function of contract and the symbiotic relationship between the development of legal institutions and individuals' bargains or promises. Llewellyn combined cultural anthropology, economic theory and examples from actual business practice to probe the texture and reality of contract arrangements. He used non-legal materials to address, in an indirect and subtle way, contemporary technical legal controversies over promissory estoppel, adhesion contracts, firm offers, and the equivalency or adequacy of consideration-so indirect and subtle that it was often impossible to tell where Llewellyn's description ended and his prescription for reform began. For example, he argued that:

law early serves a prime function in offering means of dealing with some types of dispute not otherwise adjusted. Along with this goes a recurrent tendency for law to set itself up as the exclusive means for dealing with any dispute, if it be appealed to. Law regularly purports to speak for the group as a whole, which means a pressure to draw into its orbit any other important institution; it is the other institutions which offer the stuff of disputes. Finally, rarely until modern times has expansion of jurisdiction been unprofitable to the lawmen concerned. The chief countertendency to this expansion is found in law's own formalism, and in the traditionalized character of the molds within which lawmen must move if their action is to have standing as official. Given then promises present, relied on and broken, law will sooner or later wrestle with their breach, whether or not the society peculiarly requires such wrestling. ${ }^{125}$

R.XXIII.7). Llewellyn, of course, later dedicated his case book on sales to Williston. K. LLEWELLYN, CASES AND Materials on the LAW OF Sales (1930).

122. A carbon of Llewellyn's manuscript with notations of the date received, the number of words and the number of words assigned noted, is in the Pound Papers, 13-9.

123. Id.

124. Llewellyn's article, only slightly altered, appears as Llewellyn, Contract, 4 ENCYCLoPaEDIA OF THE SOCIAL SCIENCES 329 (1931). This article is somewhat cryptically written in choppy sentences and fragments. Llewellyn later published a clearer, less adumbrated (though not substantially different) version of his article. See Llewellyn, What Price Contract? - An Essay in Perspective, 40 Yale L.J. 704 (1931) [hereinafter Llewellyn, Perspective].

125. Llewellyn, Contract, supra note 123, at 331. This quote is typical of the style of the article which is far from standard encyclopedia fare. The later version in the Yale Law Journal is aptly 
Llewellyn's draft represented his first substantive application of Legal Realism, but it was hardly a success. ${ }^{126} \mathrm{He}$ had compressed insights requiring book-length exposition into only a few pages, resulting in such density of argument and obscurity of allusion that the assigned topic-contract-suffered near obliteration. Johnson told Pound, "I think you will agree with me that the article on Contract is so important that we should make some effort to remedy the situation it has created."127 Johnson pleaded with Pound to come to his aid: "You are the only person who can do an article on the theories of contract within the three, or at the very most four, weeks within which we shall require it."128 Johnson outlined what he had in mind:

Presuinably it will deal largely with continental theories although I suppose a comparison with coinmon law attitudes would be interesting. I should say, perhaps, that we are less interested in the theories themselves which were often doubtless ill conceived than in the sociological factors of which they were a inanifestation. ${ }^{129}$

Johnson's request was right up Pound's alley. Pound reveled in synthesizing and coinparing continental thinkers to common law theorists. ${ }^{130}$

Johnson asked for something else as well. He suggested, "In doing the article I wonder finally if it wouldn't be possible for you to work in interstitially some of the more techurical rules as to the formation and discharge of contracts by way of showing that no theory fits all of thein."131 Apparently (and not surprisingly) Johnson found this another "weakness" of Llewellyn's contribution. Johnson told Pound, "These technical rules are also slighted in the article we now have, and while we are not interested in technicalities as such, I think that they are to a certain extent essential to a philosophical grasp of contract law." 132

Johnson seeins to have missed the point that Llewellyn had made, both in his Columbia Law Review article the year before ${ }^{133}$ and in the manuscript he submitted to Johnson. For Llewellyn, technical rules lacked importance in the abstract; the crucial thing to understand about

subtitled An Essay in Perspective, since the entire piece is Llewellyn's very personal vision. Llewellyn, Perspective, supra note 124.

126. Indeed, according to Corbin, Llewellyn's mentor, Samuel Williston, did not even understand the expanded version of the Encyclopaedia article, What Price Contract, when the latter appeared in the Yale Law Journal later that year. Letter from Arthur Corbin to Llewellyn, (Aug. 7, 1931) (Llewellyn Papers, R. III. 15).

127. Letter from Alvin Johnson to Roscoe Pound (Jan. 12, 1931) (Pound Papers, 13-9).

128. $I d$.

129. Id.

130. See supra text accompanying notes $22-23$.

131. Letter from Alvin Johnson to Roscoe Pound (Jan. 12, 1931) (Pound Papers, 13-9).

132. Id.

133. Llewellyn, Next Step, supra note 3. 
contract law was the reahty of transactions. Llewellyn deliberately rebelled against the notion that technical rules were essential to a inodern philosophy of contract law. ${ }^{134}$ As obscure as Llewellyn's piece may have been, it had atteinpted to reflect the reality behind the rules.

Johnson told Llewellyn that Pound had been asked to help on the article by writing some additional sections, but that Pound had advised Johnson that Llewellyn's piece required inore substantive revision. Johnson also told Llewellyn that the Harvard dean would phone him about collaborating on the revised contribution. ${ }^{135}$ Llewellyn agreed with Johnson's plan and awaited Pound's call. Confusion in Pound's office led to misunderstanding and Pound never telephoned Llewellyn. ${ }^{136}$ Finally, Llewellyn wrote to Pound. ${ }^{137}$ Pound, busy as always, reassured Llewellyn that he was willing to help and that "you have the material already in inanuscript for the bulk of an article and that with a few suggestions I can make, which I hope might appeal to you, it will not be difficult nor take inuch time to put together something which would satisfy the editor's purposes." 138 Pound suggested that they meet in New York to discuss the matter.

Messages between the two men to arrange a meeting went awry. ${ }^{139}$ Pound complained to Johnson that Llewellyn was avoiding him. ${ }^{140}$ Johnson passed on Pound's complaint to Llewellyn, whereupon Llewellyn wrote Pound to ask "wherein I failed to open the road to collaboration." 141 Llewellyn clearly had doubts about a collaboration; he told Pound that "[i]t is rarely a satisfactory business, at best . . ."142 Pound rephied that "collaboration is apt to be an awkward matter but [1] had hoped that our views on many things were so alike that we could probably

134. Llewellyn's manuscript is essentially the same as the published article. See Llewellyn, Contract, supra note 124.

135. Llewellyn recounted his telephone conversation with Johnson in a letter to Pound on Feb. 2, 1931 (Pound Papers, 24-6). He gave a more detailed chronology of events in a letter to Pound a weck later. Letter from Llewellyn to Pound (Feb. 10, 1931).

136. Letter from Pound to Llewellyn (Feb. 4, 1931) (Pound Papers, 24-6). One may speculate, given the content of Llewellyn's draft, that Pound did not want to collaborate on it at all. Llewellyn's piece was too personal in tone and too idiosyncratic in thesis for Pound to decipher, much less to join as a co-author. Pound was a master at avoiding confrontation, as the Sacco-Vanzetti affair bears witness. If my surmise about Pound's reaction to the draft is valid, Pound's inability to contact Llewellyn at crucial times would have been deliberate.

137. Letter from Llewellyn to Pound (Feb. 2, 1931) (Pound Papers, 24-6).

138. Letter from Pound to Llewellyn, (Feb. 4, 1931) (Pound Papers, 24-6).

139. Id.

140. Letter from Llewellyn to Pound (Feb. 10, 1931); Letter from Pound to Llewellyn (Feb. 12, 1931) (Pound Papers, 24-6).

141. Letter from Llewellyn to Pound (Feb. 10, 1931) (Pound Papers, 24-6).

142. Id. 
give Johnson what he wants after a conference."143 Since the two men couldn't agree on a time or place to meet, however, Pound recommended that "if you were willing to let me draw a draft incorporating a good part of yours I would submit it to you and very likely you and I could agree on something to appear as a joint project." 144 Llewellyn overcame his reluctance and wrote back to Pound on February 16, 1931, that "I will go with you on any such lime of collaboration as you suggest. It would be very interesting to work over the redraft that you speak of." 145 Three days later Johnson sent Pound Llewellyn's latest version of the article for Pound to revise. ${ }^{146}$

The correspondence between Llewellyn and Pound about the Encyclopedia article abruptly ends at this point. Instead of the collaboration upon which they had finally agreed, the Encyclopedia ultimately published an article in two parts, separately authored by Pound and Llewellyn. ${ }^{147}$ A comparison of Llewellyn's and Pound's independent pieces show that whereas Pound's comparative and doctrinal analysis took a more conventional approach than Llewellyn's, it was not terribly out of touch with nor contradictory of the latter's. They both condemned Formalism and approved of modern developments in contract law, though Llewellyn's approach was more imaginative. Their differing approaches may be illustrated by relatimg an anecdote from their later correspondence. Llewellyn, an amateur poet, sent Pound a copy of one of his poems, "The Common Law Tradition."148 Pound, no poet, wrote to Llewellyn:

143. Letter from Pound to Llewellyn Feb. 12, 1931 (Pound Papers, 24-6) (emphasis added).

144. Id.

145. Letter from Llewellyn to Pound (Feb. 16, 1931) (Pound Papers, 246).

146. Letter from Alvin Johnson to Pound (Feb. 19, 1931) (Pound Papers, 13-9).

147. Llewellyn, Contract, supra note 98, at 323-39. Letter from Pound to Llewellyn (Nov. 10, 1941) (Llewellyn Papers, R.XVI.5) (original) (Pound Papers, 142-46, contains a carbon copy).

148. Poem enclosed with letter from Llewellyn to Pound, undated (Pound Papers, 142-46):

THE COMMON LAW TRADITION

Air: Pelagius lived in Carte-Noël.

Come gather and sing to the Common Law whose twigs and nuts we are,

whether we live by the waggling jaw or counsel, miles from the Bar.

The wood is good and the sap is strong that gave us Coke and Hale,

and Right is a battle to win from Wrong,

in spite of contempt and jail.

It calls for brain and it calls for will, but an acorn knows his mission:

Law is the Oak of Liberty still, in the Common Law Tradition. Rowdy-dowdy-doodle-ee-o- 
like everything that comes from your pen, it is lively and pointed. You certainly have the swing of one of Kipling's ballads. I have never been tempted to essay verse. Indeed, I am not adapted to write it. But if I ever did attempt to write in verse about law, I should be tempted to try the style of Lucretius, and the result would, no doubt, fall very flat. ${ }^{149}$

While Pound's and Llewellyn's styles of exposition differed, their views of modern contract law were reconcilable. What happened suddenly to derail the collaboration on which they had agreed? Only a few weeks after Llewellyn agreed to let Pound rework and rewrite his "Contract" article, Pound published his Harvard Law Review critique of the Realists. All during the time that they had corresponded, Pound never himted that he had been working on such a piece. Llewellyn's later con-

\footnotetext{
In the Common Law Tradition.

Rowdy-dowdy-doodle-ee-o-

In the Common Law Tradition.

John Adams who fought in Faneuil Hall when the Bell rang down a king

had risked his all on a lawyer's call, lest England's Prescott swing.

It's learning geared to a zest for deeds has made our Common Law;

the men she needs are the men she breeds, men with a fighting jaw.

No Rule was ever enough to halt corruption or ambition

till manned by lawyers who earn their salt

in the Common Law Tradition.

The names we learned while the mazda burned put life into the letter names of judges who never turned from making the morrow better;

Cardozo, Ruffin, Burch and Shaw, and Holmes and Hough and Hand,

to changing need they shaped the Law, and ever their way shall stand.

Some say our Law's in a sorry plight, and prey to all perdition.

The answer to that is to set it right,

in the Common Law Tradition.

So sing Brandeis, Ruffin, Burch and Doe, sing Campbell, Cooley, Cowen,

Amidon, Lumpkin - up they go! The blind ones sing we down:

Each name that wrought at the mighty Bench our weal in peace and war

had served like us in the front-line trench: he fought at the Bar before -

It calls for brain and it calls for will, but an acorn knows his mission:

Law is the Oak of Liberty still, in the Common Law Tradition. 149. $I d$.
} 
duct and comments indicate that he felt betrayed. ${ }^{150} \mathrm{He}$ told his mentor and confidante, Arthur Corbin, "I still can't understand how he could write the article."151

\section{CONCLUSION}

The personal breach between Llewellyn and Pound did not last. After Llewellyn's "Some Realisin-Reply to Pound" article, they resumed a warm correspondence that continued for nearly two decades. Llewellyn also revised his valuation of Pound. In his courses on Jurisprudence at Columbia and Chicago, Llewellyn frequently lectured about Pound's contribution. He told his students "that of all the 20th century jurisprudents, Pound was the only one, the only one, who had sense enough to see that each of these outfits [jurisprudential approaches] had its contribution and to atteinpt to gather thein into a whole- a great contribution indeed." $152 \mathrm{He}$ candidly concluded on another occasion that

Pound is, after all, a terrific figure. You can get mad at him as hell, as I do, and you can regard him as four times of a self-made s.o.b.

150. Twining recognized Llewellyn's seuse of betrayal, but thought it was only because Pound had sent Llewellyn such a nice note after the Next Step article. W. TwINING, supra note 25, at 7273. Collaboration is an intimate relationship. When one author agrees to collaborate with another, there is, by necessity, a bond created between them not unlike the bond created in marriage. You place your trust in your coauthor. You feel vulnerable. Betrayal of that trust by public attacks upon you by your coauthor is akin to discovering the infidelity of your spouse. Llewellyn's perceived betrayal by his ostensible collaborator, Pound, enraged him. Llewellyn's rage manifested itself in several ways: When Llewellyn wrote "Some Realisin About Realism: A Reply to Dean Pound," when he refused to include Pound in his list of Realists, and when he authored the never-published footnote that denied Pound any connection to the intellectual history of the new Jurisprudence, Llewellyn was blotting out all that had been between them and restoring some of his self respect.

Llewellyn's actions-the Reply article itself and the unpublished footnote-remind me of a scene in Paul Mazursky's film, An Unmarried Woman. After Jill Clayburgh's husband, Michael Murphy, left her for a younger woman, she tore through their apartment throwing out every item even remotely connected to her unfaithful husband to the extent of tearing off his visage from pictures of the two of them. An Unmarried Woman (Twentieth Century Fox 1977).

I am not unique in comparing Llewellyn's collaborations to marriage. Llewellyn's biographer, William Twining, compared Llewellyn's later collaboration with E. Adamson Hoebel, with whom he wrote THE CheyenNe WAY (1941), to a marriage: "Interdisciplinary matchmakers might learn something about the conditions of successful collaboration from this unique example of a marriage between law and anthropology which lasted until the death of one of the partners." W. TwINING, supra note 36, at 167. Although the "marriage" to Hoebel may have lasted until Llewellyn's death, that does not mean less permanent collaborations, such as the abortive one with Pound, may not also be compared to marriage. Not all marriages are permanent; Llewellyn hinself had two marriages end in divorce (to Elizabeth Sanford (married in 1924, divorced in 1930) and Emma Corstvet (married in 1933, divorced in 1946)). Id. at 109-10.

151. Letter from Llewellyn to Arthur Corbin (Apr. 6, 1931) (Llewellyn Papers, A.II.65(b)).

152. Llewellyn, Jurisprudence Lectures, Lecture IX (Llewellyn Papers, C.H.1-40). 
in many ways, which he is, and none of that detracts from the greatness and from the power that is there. ${ }^{153}$

Llewellyn's later lectures notwithstanding, the damage to Pound's reputation and the Progressive-Pragmatic jurisprudential movement he represented was irreparable. When Llewellyn got "mad at him as hell" in 1931, Llewellyn effectively rewrote the history of twentieth-century jurisprudential development. Realism became the focus of attention for jurisprudential scholars and was portrayed thereafter as the primary challenger of nineteenth-century Formalism. He eliminated Pound's Progressive-Pragmatic, anti-Formalist inovement as a jurisprudential entity and the stem froin which Reahstic Jurisprudence itself was really only an off-shoot. Politics and personality led Llewellyn to kill off Progressive-Pragmatisin and invent Legal Realism.

The history of Jurisprudence is always written in terms of movements and doctrimes, but as the contextualist historian will tell you, the story is lived by real inen and women whose ideas and expressions of those ideas-whetlier in correspondence or public forums-are predominantly influenced by the conditions of their lives. These conditions include their mvolvement in the great intellectual and inoral crises of their times as well as these Jurisprudents' interaction with each other. It is this dimension which tlie listorian tries to reconstruct from her sources. New doctrine is thus less a product of prior doctrine in some sort of genetic mutation, and more a historical artifact of human controversy and action.

153. Llewellyn, Jurisprudence Lectures, Lecture XII (Apr. 24, 1953) (Llewellyn Papers, C.L.120). 